\title{
Sexual consequences of female genital mutilation/cutting : comparative study
}

\author{
Original \\ Article \\ Samy Hanafy ${ }^{1}$, Doaa El-Habak ${ }^{1}$, Mona El-Awady ${ }^{2}$ and Marwa Abdou ${ }^{1}$ \\ Departments of ${ }^{1}$ Dermatology and Andrology and ${ }^{2}$ Community Medicine, Faculty of \\ Medicine, Benha University, Benha, Egypt
}

\begin{abstract}
Background: Female genital mutilation/cutting (FGM/C) is still a wide spread practice in Egypt in spite of its criminalization in 2008 .

Objective: This cross sectional study was carried out to assess female sexuality in a large cohort of Egyptian women exposed to FGM/C compared to those who were not exposed to it.

Patients and Methods: A large sample of married Egyptian women participated in this study. They were divided into 2 equal groups (1000 women each). Group A contained women who were not exposed to FGM/C while group B contained women exposed to FGM/C. The tool used was a self-report questionnaire, designed by the authors, and anonymously filled by the participants. The questionnaire involved questions that mainly covered demographic data and sexual activity of the participating women.

Results: By comparing all age groups, our results reflect a retreat in FGM/C practice. A significant difference was observed in all sexual domains in favor of women not exposed to FGM/C including spontaneous desire, lubrication, orgasm and overall satisfaction with sexual life. In addition, dyspareunia was more common in genitally cut women.

Conclusion: Although FGM/C is on the retreat, still it has negative consequences on female sexuality. Results of this study may be of use during treating women with sexual dysfunctions.
\end{abstract}

Key Words: Female, genital mutilation, sexual activity.

Received: 09 May 2019, Accepted: 22 November 2019

Corresponding Author: Doaa El-Habak, MD, Department of Dermatology and Andrology, Faculty of Medicine, Benha University, Benha, Egypt, Tel.: 01022081802, E-mail: doaadermat@yahoo.com

ISSN: 2090-6048, June 2019 Vol.9, No.2

\section{INTRODUCTION}

Female genital mutilation/cutting (FGM/C)comprises all procedures that involve partial or total removal of the external female genitalia, or other injury to the female genital organs for non-medical reasons ${ }^{[1]}$.

Four types of FGM/C are recognized. Type I: Clitoridectomy; partial or complete excision of the clitoris and/or the prepuce. Type II: Excision; partial or complete removal of the clitoris and labia minora, with or without removal of labia majora. Type III: Infibulation; reduction of the vaginal orifice with a seal formed by cutting and repositioning of labia minora and/or labia majora, with or without removal of the clitoris. Type IV: All other harmful procedures to the genitalia such as pricking, piercing, incising, scraping and cauterization. In Egypt types I and II are the most frequently used methods while Types III and IV are fairly rare $^{[2]}$.

Historical antecedents and social research revealed that FGM/C was practiced by the Phoenicians,Hittites and ancient Egyptians. England and the United States used
FGM/C to treat hysteria,lesbianism, masturbation and other female deviances in the $1940 \mathrm{~s}$ and $1950 \mathrm{~s}^{[3]}$.

FGM/C remains the norm in some countries despite numerous legislativeand programmatic interventions that encourage communities to abandon the practice ${ }^{[4]}$. Worldwide, more than 200 million women and girlshave undergone $\mathrm{FGM} / \mathrm{C} / \mathrm{C}$ and every year a further 3 milliongirls are expected to undergo the procedure in countrieswhere the practice is prevalent ${ }^{[5]}$.

A recent Australian study ${ }^{[6]}$ tried to assess the effect of FGM/C on maternal and neonatal outcomes by comparing women affected by $\mathrm{FGC} / \mathrm{C}$ to women unaffected by it. There was no difference in cesareansection rate. Women with $\mathrm{FGM} / \mathrm{C} / \mathrm{C}$ were less likely to be delivered by vacuum or forceps. There was no difference in perineal trauma,postpartum hemorrhage and neonatal nursery admission. Women with FGM/C type 3 were more likely to have an episiotomy without anincrease in anal sphincter injury.

An Egyptian study ${ }^{[7]}$ on 204 girls, aged 14-19 years, 
found that FGM/C girls had a significantlyhigher level of psychological problems with regard to somatization, depression, anxiety, phobicanxiety and hostility compared with non-FGM/C/C girls.

Berg and Denison ${ }^{[8]}$ conducted a meta-analysis of a total of 15 studiesto answer the question: does female genital mutilation/cutting (FGM/C/C) affect women's sexual functioning? Results showed thatcompared to women without $\mathrm{FGM} / \mathrm{C} / \mathrm{C}$, women who hadbeen subjected to $\mathrm{FGM} / \mathrm{C} / \mathrm{C}$ were more likely to reportdyspareunia, no sexual desire and less sexual satisfaction.

\section{AIM OF THE STUDY}

The existing literature is unclear about the effects $\mathrm{FGM} / \mathrm{C}$ has on sexual function and desire ${ }^{[9-10]}$. The current study wascarried out to assess female sexuality in a large cohort of Egyptian women exposed to FGC/M compared to those who were not exposed to it.

\section{PATIENTS AND METHODS}

The current study was a comparative cross-sectional study that carried out between April 2016 and September 2018. Work started after approval of the Committee of Medical Ethics and the Dermatology and Andrology Department, Benha University and all participants gave an informed consent.

Participants were 2000 Egyptian married women with regular sexual relations. They were recruited from attendants of the Outpatient Clinic of Hod El-Marsood Hospital in Cairo. Participants were divided into 2 groups: Group A: One thousand genitally uncut women. Group B: One thousand genitally cut women.

Exclusion criteria were presence of any medical conditions affecting female sexuality e.g. neuropsychiatric diseases and liver and renal failure. Also, Women unable to fill the questionnaire by themselves were excluded to allow for anonymity of subjects to obtain the most possible truthful responses.

The tool used was a self-report questionnaire designed by the authors and included 19 items for group A and 15 items for group B covering the following points:
1. Epidemiological data:e.g. age, age of marriage, educational level etc...

2. Data about genital cutting (for group 2) e.g. who took the decision to do FGM/C and who performed it.

3. Female sexual activity e.g. libido, coital frequency, orgasm etc...

4. Assessing participants' opinion about continuity of genital cutting in the next generations.

Each questionnaire was handed in an open envelope and after filling it; the subject sealed it and put it in a basket containing other sealed envelopes.

\section{Statistical Analysis}

The clinical data were recorded on a report form. These data were tabulated and analyzed using the computer SPSS program version 20 (SPSS Inc., Chicago, IL). Comparisons between different groups and the significance of difference were tested using chi square test (x2-value) and Fisher exact test (FET). Statistical significance was set at $p$ value $<0.05$.

\section{RESULTS}

Table 1 indicates that living in an urban area, having a job and having a better level of education are associated with a less possibility of being affected by FGM/C. Comparing age groups shows that the percentage ofwomen exposed to $\mathrm{FGM} / \mathrm{C}$ was more in all age groups which reflects that this procedure is retreating.

There were significant differences in sexuality between women exposed to $\mathrm{FGM} / \mathrm{C}$ and those not exposed to it. Genitally cut women showed a higher percentage of a coital frequency of less than once/month, a higher percentage of never having a spontaneous desire, a higher percentage of rare or never having lubrication during coitus and their ability to obtain orgasm was less than those not exposed to FGM/C. Dyspareunia occurred more in genitally cut women and their overall satisfaction with their sexual life was less than uncut women (Table 2).

Table 3 indicated that mothers are the main decision maker for $\mathrm{FGM} / \mathrm{C}$ in the family. However, $73 \%$ of cut women said that they will not expose their daughters to $\mathrm{FGM} / \mathrm{C}$. 
Table 1: Demographic data.

\begin{tabular}{|c|c|c|c|c|c|c|c|c|c|}
\hline & & \multicolumn{2}{|c|}{$\begin{array}{l}\text { Cut women } \\
(\mathrm{n}=1000)\end{array}$} & \multicolumn{2}{|c|}{$\begin{array}{l}\text { Uncut women } \\
\qquad(\mathrm{n}=1000)\end{array}$} & \multicolumn{2}{|c|}{$\begin{array}{l}\text { Total } \\
(2000)\end{array}$} & \multirow{2}{*}{ Statistical test } & \multirow{2}{*}{$P$ value } \\
\hline & & $\mathrm{n}$ & $\%$ & $\mathrm{n}$ & $\%$ & $\mathrm{n}$ & $\%$ & & \\
\hline \multirow{7}{*}{ Age } & $20>$ & 21 & 2.1 & 1 & 0.1 & 22 & 1.1 & \multirow{7}{*}{$\mathrm{FET}=320.6$} & \multirow{7}{*}{$<0.001^{* *}$} \\
\hline & $20-29$ & 186 & 18.6 & 512 & 51.2 & 698 & 34.9 & & \\
\hline & $30-39$ & 709 & 70.9 & 486 & 48.6 & 1195 & 59.8 & & \\
\hline & & & & & & & & & \\
\hline & $40-49$ & 68 & 6.8 & 1 & 0.1 & 69 & 3.4 & & \\
\hline & $50-59$ & 12 & 1.2 & 0 & 0.0 & 12 & 0.6 & & \\
\hline & $>60$ & 4 & 0.4 & 0 & 0.0 & 4 & 0.2 & & \\
\hline \multirow{3}{*}{ Age of marriage } & $20>$ & 69 & 6.9 & 37 & 3.7 & 106 & 5.3 & \multirow{3}{*}{$\mathrm{X}^{2}=12.29$} & \multirow{3}{*}{$0.002^{* *}$} \\
\hline & $20-29$ & 896 & 89.6 & 938 & 93.8 & 1834 & 91.7 & & \\
\hline & $30-39$ & 35 & 3.5 & 25 & 2.5 & 60 & 3.0 & & \\
\hline \multirow{3}{*}{ Work } & Working & 714 & 71.4 & 891 & 89.1 & 1605 & 80.2 & \multirow{3}{*}{$\mathrm{X}^{2}=98.83$} & \multirow{3}{*}{$<0.001^{* *}$} \\
\hline & & & & & & & & & \\
\hline & Not working & 286 & 28.6 & 109 & 10.9 & 395 & 19.8 & & \\
\hline \multirow{3}{*}{ Residence } & In a city & 749 & 74.9 & 848 & 84.8 & 1597 & 79.8 & \multirow{3}{*}{$X^{2}=46.2$} & \multirow{3}{*}{$<0.001^{* *}$} \\
\hline & In a town & 85 & 8.5 & 83 & 8.3 & 168 & 8.4 & & \\
\hline & In a village & 166 & 16.6 & 69 & 6.9 & 235 & 11.8 & & \\
\hline \multirow{3}{*}{ Education level } & Can only read and write & 102 & 10.2 & 1 & 0.1 & 103 & & \multirow[t]{3}{*}{$X^{2}=270.1$} & \multirow[t]{3}{*}{$<0.001^{* *}$} \\
\hline & Finished secondary school & 227 & 22.7 & 45 & 4.5 & 272 & & & \\
\hline & Have a university degree & 671 & 67.1 & 954 & 95.4 & 1625 & & & \\
\hline
\end{tabular}


Table 2: Effect of genital cutting on sexual activity and overall satisfaction.

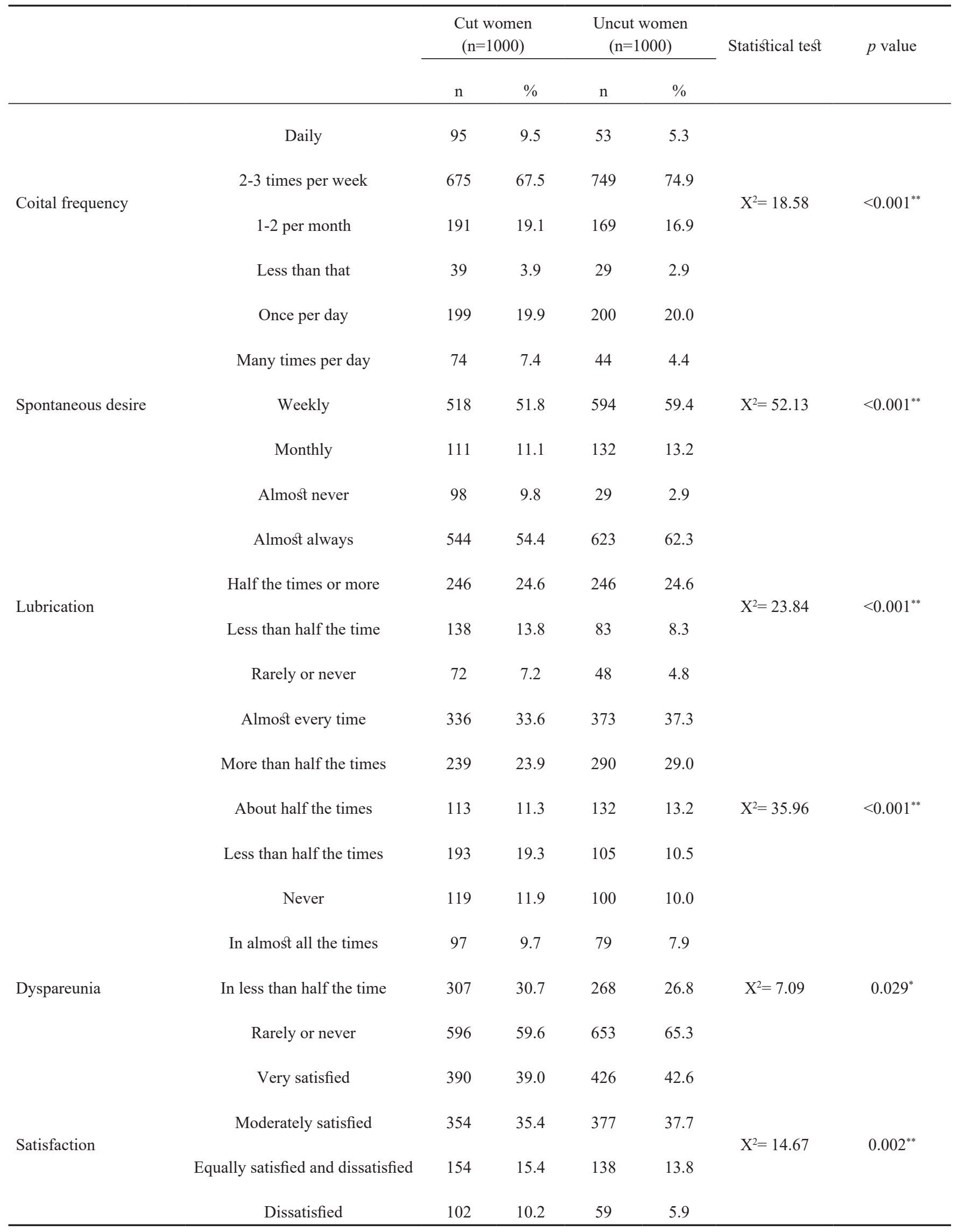

${ }^{*} p>0.05$ (significant), ${ }^{* *} p>0.01$ (highly significant). 
Table 3: Social aspects.

\begin{tabular}{|c|c|c|c|}
\hline & & \multicolumn{2}{|c|}{$\begin{array}{l}\text { Cut women } \\
(n=1000)\end{array}$} \\
\hline & & $\mathrm{n}$ & $\%$ \\
\hline \multirow{4}{*}{ Who usually take decision of genital cutting } & Father & 284 & 28.4 \\
\hline & Mother & 653 & 65.3 \\
\hline & Grandmother & 87 & 8.7 \\
\hline & Others & 31 & 3.1 \\
\hline \multirow{3}{*}{ Will you expose your daughters to FGM/C? } & Yes & 75 & 7.5 \\
\hline & No & 730 & 73.0 \\
\hline & Don't know & 195 & 19.5 \\
\hline
\end{tabular}

\section{DISCUSSION}

Female Genital Mutilation continues to persist despite its illegality because of social pressureon women/girls to conform to social norms, peer acceptance, fear of criticism andreligious reasons. Implementing interventions targeting religious leaders andtheir followers, older men and women and younger men and women will help eradicate thepractice ${ }^{[11]}$. Although the previous statement reflects the findings of a recent study in Ghana, the same may be applicable to Egypt as the present study found that mothers and grandmothers are the main decision makers concerning FGM/C. High education and having a job are predictors of abandoning this tradition according to the findings of the present study.

Shaeer and Shaeer ${ }^{[12]}$ found that an important motivation driving FGM/C seems to be males seeking female chastity rather than religion, especially with FGC not being an Islamic mandate, not to undermine the importance of religion among othermotives.

The current study indicates that the tradition of $\mathrm{FGM} / \mathrm{C}$ is retreating. Younger women were less exposed to $\mathrm{FGM} / \mathrm{C}$ and $73 \%$ of cut women said that they will not circumcise their daughters. Alkhalaileh et al. ${ }^{[13]}$ assessedthe extent to which prevalence of $\mathrm{FGM} / \mathrm{C} / \mathrm{C}$ have changed in Egypt since its criminalization in 2008. They reported that the prevalence of $\mathrm{FGM} / \mathrm{C} / \mathrm{C}$ among adolescent womenstatistically significantly decreased from $94 \%$ in 2008 to $88 \%$ in 2014.Among the participants of Moamen et al. ${ }^{[14]}$, all the uncircumcised women as well as $40 \%$ of circumcised participants disagreed with performing circumcision on their daughters and said that it is not important, is unnecessary for a woman, and is a painful procedure.

A low coital frequency (1-2/month or less) was reported more by genitally cut women. However, this is not an important factor as this frequency is guided largely by the husband.

The frequency of spontaneous sexual desire was lower in our cut participants than the uncut ones. In accordance, Thabet and Thabet ${ }^{[15]}$ found that women who had been subjected to $\mathrm{FGM} / \mathrm{C}$ reported lower sexual desire and arousal scores. Also, Berg et al.$^{[8]}$ found that women with $\mathrm{FGM} / \mathrm{C}$ were twice as likely to report that they experienced no desire compared to women without FGM/C. Other studies reported similar results ${ }^{[10,16]}$.

The presence of adequate lubrication during sexual encounters was reported more by our uncut participants than cut ones.Al-Sibiani and Rouzi ${ }^{[9]}$ reported similar findings with a significantly higher lubrication scores among genitally uncut women. Other studies ${ }^{[13,17]}$, however, found no statistically significant difference between the two groups.

In our study, we found that the frequency of orgasm was lower in the genitally cut women than the uncut ones. This result was supported by the study of Moamen et al. ${ }^{[14]}$; where there were statistically significant differences in arousal and orgasm scores detected between the genitally cut and uncut women, with higher scores among genitally uncut women, which were more evident above the age of 30 years. Also, this result agreed with ${ }^{[9,15,18-19]}$ who also found that the cut women were less orgasmic than uncut ones, 
that can be explained as women experienced two kinds of orgasm clitoral and vaginal. For cut women clitoral orgasm might be decreased according to the type of FGC but the cut women still experience the vaginal orgasm so FGC reduced the capacity of women to reach orgasm ${ }^{[18-19]}$.

The present study found that dyspareunia was higher in genitally cut women than the uncut ones. Berg and Denison $^{[16]}$ and Ismail et al. ${ }^{[2]}$ observed that women who had been subjected to FGM/C (type I/II) were 1.5 times more likely to experience pain duringintercourse than women who had not been subjected toFGM/C.Other workers from Iran ${ }^{[20]}$, rural Gambia ${ }^{[21]}$, and rural Ghana ${ }^{[22]}$ reported thatwomen with $\mathrm{FGM} / \mathrm{C}$ are more likely to report dyspareunia than women who had not been subjected toFGM/C. On the other hand, Alsibiani and Rouzi ${ }^{[9]}$, in Saudi Arabia, found no difference in the mean pain score. After studying 650 women (including 333 who were exposed to FGM/C), the conclusion of Anis et al. ${ }^{[23]}$ was that in Egyptian women, FGC is associated with reduced scores of the Arabic Female Sexual Function Indexon all domain scores except the sexual pain domain.

\section{LIMITATIONS OF STUDY}

Exclusion of illiterate women makes the study results less representative of a broad sector of Egyptian women.

\section{CONCLUSION}

FGM/C may have a negative impact on female libido, lubrication, orgasm, dyspareunia and overall satisfaction in cut women. Sexologists should put in mind these negative effects when providing care for sexually dysfunctional women who already had undergone FGM/C.

\section{CONFLICT OF INTEREST}

There are no conflicts of interest.

\section{REFERENCES}

1. WHO. Female genital mutilation is recognized internationally as a violation of the human rights of girls and women: fact sheet. World Health Organization; 2014.

2. Ismail SA, Abbas AM, Habib D, Morsy H, Saleh MA, Bahloul M. Effect of female genital mutilation/ cutting; types I and II on sexual function: casecontrolled study. ReprodHealth 2017 30;14(1):108

3. Sakeah E, Debpuur C, Aborigo RA, Oduro AR, Sakeah JK, Moyer CA. Persistent female genital mutilation despite its illegality: Narratives from women and men in northern Ghana. PLoSOne 2019 22;14(4):e0214923.
4. Koski A, Heymann J. Changes in support for the continuation of female genital mutilation/cutting and religious views on the practice in 19 countries. Glob Public Health. 2019; 14(5):696-708.

5. United Nations Children's Fund. Female genital mutilation/cutting: a global concern. New York (NY): UNICEF; 2016.

6. Davis G, Jellins J. Female genital mutilation: Obstetric outcomes in metropolitan Sydney. Aust N Z J ObstetGynaecol2019;59(2): 312-316.

7. Ahmed MR, Shaaban MM, Meky HK, Amin Arafa ME, Mohamed TY, Gharib WF, Ahmed AB. Psychological impact of female genital mutilation among adolescent Egyptian girls: a crosssectional study. Eur J ContraceptReprod Health Care 2017 ; 22(4):280-285.

8. Berg RC, Denison E. Does female genital mutilation/ cutting (FGM/C) affect women's sexual functioning? A systematic review of the sexual consequences of FGM/C. Sex Res Soc Policy 2012 1;9(1):41-56.

9. Alsibiani SA, Rouzi AA. Sexual function in women with female genital mutilation. FertilSteril 2010 1;93(3):722-4.

10. Biglu MH, Farnam A, Abotalebi P, Biglu S, Ghavami M. Effect of female genital mutilation/cutting on sexual functions. Sex Reprod Health 2016 1;10:3-8.

11. Sakeah E, Debpuur C, Aborigo RA, Oduro AR, Sakeah JK, Moyer CA. Persistent female genital mutilation despite its illegality: Narratives from women and men in northern Ghana. PloS one $201922 ; 14(4)$.

12. Shaeer O, ShaeerE.The Global Online Sexuality Survey: public perception of female genital cutting among internet users in the Middle East. J Sex Med 2013;10(12):2904-11.

13. Alkhalaileh D, Hayford SR, Norris AH, Gallo MF. Prevalence and attitudes on female genital mutilation/ cutting in Egypt since criminalization in 2008. Cult Health Sex $2018 ; 20(2): 173-182$.

14. Moamen MN, Mohamed TA, Idris OA, El Emam DA. Incidence of arousal and orgasmic disorders in women with female genital mutilation/cutting. Hum Androl2013;3(1):10-5.

15. Thabet SM, Thabet AS. Defective sexuality and female circumcision: the cause and the possible management. J Obstet Gynaecol Res 2003 ; 29(1):12-9. 
16. Berg RC, Denison E. Does female genital mutilation/ cutting (FGM/C) affect women's sexual functioning? A systematic review of the sexual consequences of FGM/C. Sex Res SocPolic 2012;9(1):41-56.

17. Catania L. Defibulation: A practice to improve the quality of infibulated women's life. Female and male genital surgeries: Critical intersections/astonishing issues. InAbstract Book of the 10th Annual Meeting American Anthropological Association. Critical Intersections/Dangerous Issues, San Jose, California. American Anthropological Association: Arlington, VA 2006 Nov 15 (Vol. 167).

18. El-Defrawi MH, Lotfy G, Dandash KF, Refaat $\mathrm{AH}$, Eyada M. Female genital mutilation and its psychosexual impact. J Sex Marital Ther 2001;27(5):465-73.

19. Elnashar A, Abdelhady R. The impact of female genital cutting on health of newly married women. Int J Gynaecol Obstet. 2007;97(3):238-44.

20. Biglu MH, Farnam A, Abotalebi P, Biglu S, Ghavami M. Effect of female genital mutilation/cutting on sexual functions. Sex ReprodHealthc2016;10:3-8.

21. Morison L1, Scherf C, Ekpo G, Paine K, West B, Coleman R, Walraven $\mathrm{G}$. The long-term reproductive health consequences of female genital cutting in rural Gambia: a community-based survey. Trop Med Int Health 2001;6(8):643-53.

22. Odoi A, Brody SP, Elkins TE. Female genital mutilation in rural Ghana, West Africa. Int J Gynaecol Obstet. 1997;56(2):179-80.

23. Anis TH, Gheit SA, Awad HH, Saied HS. Effects of female genital cutting on the sexual function of Egyptian women. A cross-sectional study. J Sex Med 2012;9(10):2682-92. 